\title{
Familial and Economic Influences on the Gender-Related Educational and Occupational Aspirations of Rural Adolescents
}

\author{
Judith L. Meece ${ }^{1}$, Karyl J. S. Askew ${ }^{1}$, Charlotte A. Agger ${ }^{1}$, Bryan C. Hutchins ${ }^{1} \&$ Soo-yong Byun $^{2}$ \\ ${ }^{1}$ School of Education, University of North Carolina at Chapel Hill, Chapel Hill, North Carolina, USA \\ ${ }^{2}$ Department of Education Policy Studies, The Pennsylvania State University, State College, PA, USA \\ Correspondence: Judith L. Meece, School of Education, University of North Carolina at Chapel Hill, Chapel Hill, \\ North Carolina, 27599, USA. Tel: 1-919-962-9195. E-mail: meece@email.unc.edu
}

Received: March 16, 2014

doi:10.5539/jedp.v4n1p238

\author{
Accepted: April 9, 2014 \\ Online Published: April 23, 2014 \\ URL: http://dx.doi.org/10.5539/jedp.v4n1p238
}

\begin{abstract}
Economic, occupational, and social shifts in rural economies have influenced nuanced changes in the educational and occupational aspirations of rural adolescent women and men. However, there is limited contemporary research that examines the aspirations of rural adolescents at the beginning of the $21^{\text {st }}$ century. Drawing on a sample of 8,756 rural adolescents in the United States, we examine how familial, geographic, and economic variables influence gender-related differences in educational and occupational aspirations. Findings revealed significant gender differences, favoring girls, in youth's educational aspirations, occupational aspirations, and aspirations for nontraditional careers. Results highlight the importance of contextual variables such as parental expectations, family income, and motivation variables in predicting gender-related aspirations of rural youth.
\end{abstract}

Keywords: aspirations, rural youth, adolescents, educational aspirations, occupational aspirations

\section{Introduction}

Over the last several decades, rural communities have experienced distinct social, structural, and economic shifts due, in part, to technological advances and economic globalization (Brown \& Schafft, 2011; Farmer et al., 2006; US Department of Agriculture [USDA], 2013). Within the United States, rural communities have seen a marked decline in industries such as agriculture, mining, fishing, and logging. Whereas previous generations of rural youth were able to find jobs that required little postsecondary preparation, technological advancements in agriculture and a reduction in American-based manufacturing have reduced or eliminated low-skilled employment opportunities in rural locations (USDA, 2013). Along with economic and structural changes, shifts in social norms and beliefs about women's roles in the workplace have also occurred. Collectively, these changes have differentially influenced rural men and women, as many rural youth have shifted their educational and occupational aspirations to align with more contemporary economic, social, and occupational conditions. For instance, recent evidence indicates that the majority of rural youth (more than ever before) aspire to obtain a postsecondary degree (Byun, Irvin, \& Meece, 2012; Meece et al., 2013). Yet, despite this increase in overall postsecondary aspirations among rural students, the factors influencing this trend are largely unknown. That is, there is little information on how recent social and economic changes have shaped rural students' educational and occupational aspirations in the context of $21^{\text {st }}$ century advances.

Therefore, the current paper used data from 8,756 rural high school students in Grades 9 to 12 to investigate how social, structural, and economic changes have influenced the educational and occupational aspirations of rural men and women. The guiding research questions for the study were the following: (1) Are there gender differences in rural adolescents' educational and occupational aspirations? (2) Are there gender differences in factors that explain rural adolescents' educational aspirations and nontraditionality of occupational choices? and, (3) What is the relative influence of key motivation variables when controlling for individual characteristics, perceived family influence, and community characteristics?

\subsection{Aspirations and Adolescents}

The period of adolescence is a critical time of developmental exploration when students refine their educational and occupational aspirations. A substantial body of research on youth's aspirations has found that aspirations serve as predictors of postsecondary and occupational attainment in early adulthood and in subsequent years 
(Bandura, Barbaranelli, Caprara, \& Pastoerelli, 2001; Beal \& Crockett, 2010; Eccles, Vida, \& Barber, 2004; Schneider \& Stevenson, 1999). Aspirations may be conceptualized using several different theoretical frameworks; however, the current paper uses a motivation perspective to examine student aspirations. From this perspective, aspirations are cognitive representations of a goal that help direct and organize behaviors (Bandura, 1986) and can include educational or occupational hopes, desires, ambitions, and inspirations. Research has found that students who maintain a clear sense of purpose and direction are likely to make adaptive transitions into adulthood (Eccles, Brown, \& Templeton, 2008; Elder \& Conger, 2000). In addition, research on motivation and rural youth has highlighted the important role that competence- and value-related beliefs have on school completion and postsecondary plans (Hardré, Sullivan, \& Crowson, 2009).

\subsection{Aspirations and Gender}

Despite limited previous work, extant research on the gender-related aspirations of rural adolescents has revealed that male and female adolescents sometimes express different aspirations for their future schooling and employment. However, the results of this research are mixed and have changed over time.

\subsubsection{Gender-Related Educational Aspirations}

Educational aspirations serve as orientations and hopes concerning future educational attainment. Previous research on gender-related educational beliefs using rural samples has found that girls maintain higher educational aspirations than male students (Elder \& Conger, 2000; Lapan, Tucker, Kim, \& Koscuilek, 2003). Possible factors undergirding the differences in aspirations of rural girls and boys may include changes in the occupational structure of rural areas, the breakdown of social and structural barriers for girls, and differences in boys' and girls' ties to their rural roots.

Other studies have found that girls and boys hold similar levels of educational aspirations, but arrive at their aspirations via different pathways. For example, Chenoweth and Galliher (2004) found that for boys, family and peer contexts were important in predicting college aspirations. On the other hand, they found academic preparation and obstacles to attending college to be more salient for girls. These findings on gender-related differences in rural students' aspirations are important, yet extending research in this area to include more current information, larger, more geographically diverse samples of rural youth and economic and contextual variables is needed (Petrin, Schafft, \& Meece, 2014).

\subsubsection{Gender-Related Occupational Aspirations}

Similar to educational aspirations, occupational aspirations represent specific future-oriented professional or work-related ambitions and hopes. Existing research has found that, in general, occupational aspirations between male and female adolescents tend to differ. When compared to their male peers, young women often opt for less prestigious jobs in the labor market (Shapka, Domene, \& Keating, 2006) and place a greater value on jobs that allow for time spent in family roles (Eccles, 2007; Frome, Alfeld, Eccles, \& Barber, 2006). Placing a low value on many science-related domains has also steered women away from many traditionally male occupations (Frome et al., 2006). Despite consistency in these previous findings, recent work has shown that adolescent girls have become more ambitious about their future jobs compared to boys and are more likely to aspire to jobs that require numerous academic qualifications (Schoon, Martin, \& Ross, 2007; Mello, 2008; Schoon, 2006), including girls from rural communities (Lapan et al., 2003). Using rural samples, research looking at gender and occupational plans has also found that adolescent girls report more positive levels of career development than their male peers. In fact, research dating back to the early 1990s documented gender differences in rural adolescents' selection of nontraditional careers. Findings favored rural girls, when compared with their male peers (Lapan et al., 2003; Lauver \& Jones, 1991).

Although this research has greatly advanced our understanding of gendered occupational aspirations, there is still a need for more current information on gendered aspirations of contemporary rural youth in the United States and elsewhere. Few studies have considered the ways and degrees to which contextual influences (e.g., familial, geographic, etc.) shape gender-related aspirations in rural populations. Given recent social and economic changes in rural communities, it especially important to address the role of context in molding rural adolescents' aspirations.

\subsection{Contextual Influences on Adolescents' Aspirations and Development}

As our research is grounded in an ecological theoretical framework, we concentrate on the contextual influences that play a significant role in the developmental and educational trajectories of rural adolescents. For instance, family income, parental expectations, parental educational attainment, and adult role models all impact the educational and occupational attainment of rural youth (Crockett \& Bingham, 2000; Crockett, Shanahan, \& 
Jackson-Newsom, 2000; Elder \& Conger, 2000; Eccles, 2007). In addition to these family-related influences, rural youth's aspirations are shaped by broader socioeconomic circumstances (Crockett et al., 2000; Elder \& Conger, 2000; Petrin et al., 2014). In the following section, we highlight familial, geographic, and economic factors as several of the main contextually-based elements in predicting adolescent development and in doing so, we focus on elements unique to rural communities.

\subsubsection{Familial Influences}

Research has demonstrated that parental education and income are strongly associated with the development of children's educational and career aspirations (Hill et al., 2004; Hill, Ramirez, \& Dumka, 2003; McWhirter, Hacket, \& Bandalos, 1998; Meece et al., 2013). The influence of parental education and income are well documented, and the pathways of influence are multiple, ranging from structuring the home environment to supporting academic achievement to communicating high educational expectations (Eccles, Wigfield, \& Schiefele, 1998). When compared to metropolitan communities, the levels of parental education and income within rural communities tend to be lower (Crockett et al., 2000; Provasnik et al., 2007). Only a few studies to date have examined the differential influence of these familial influences for adolescent boys and girls in rural communities. Drawing on a sample of rural youth in Western Virginia, Chenoweth and Galliher (2004) found that mothers' and fathers' levels of education were significant in predicting students' plans for college, especially for adolescent boys. Relatedly, within this rural sample, family social economic status was more predictive of adolescent boys' than girls' college planning. Additional research is needed to confirm these patterns of parental influence for rural youth today.

\subsubsection{Geographic Influences}

Along with parental influences on educational attainment, there are also distinct features of rural ecologies that influence youth's development and subsequent transition to adulthood (Crockett et al., 2000; Elder \& Conger, 2000). On one hand, rural areas are geographically isolated and characterized by a high degree of social cohesion. Community members maintain close social ties, support one another, and share the responsibility of rearing young people (Dyk \& Wilson, 1999; Elder \& Conger, 2000; Stracuzzi, 2009; Rojewski, 1999). As a result of these close-knit family and community contexts, rural youth often experience tension regarding moving away to pursue postsecondary educational and occupational opportunities that are not encouraged in their hometowns or communities (Corbett, 2007; Farmer et al., 2006; Hektner, 1995). On the other hand, due to geographic isolation, rural youth preparing for the postsecondary transition face challenges regarding lack of college- and career-related resources. For instance, many urban and suburban high schools have college and career planning resources embedded in their curriculum (e.g., advanced placement courses, access to community college courses, etc.), highly qualified teachers and administrators, and career and college counseling to ensure a successful transition to work or college (Griffin, Hutchins, \& Meece, 2010; Hutchins, Meece, Byun, \& Farmer, 2012; Irvin et al., 2011). Prior studies indicate that these resources contribute to disparities in educational aspirations between rural and nonrural youth (Howley, 2006; McGranahan, 1994; Rojewski, 1999). It is not yet clear how geographical location (e.g., perception of rural community and economic opportunity) differentially shapes the future plans of men and women in rural communities.

\section{The Current Study}

\subsection{Purpose and Research Questions}

Given the multiple influences on youth's transition into early adulthood, this study examined the role of individual, familial, schooling, and community influences on aspirations of rural youth. This study used an ecological framework (Bronfenbrenner, 1979) to address various economic and contextual predictors of educational and occupational aspirations including, but not limited to, academic self-concept, perceived family economic hardship, mothers' and fathers' expectations for college education, and community poverty. As rural youth experience a host of unique geographic, economic, and social conditions, this study also hoped to highlight the importance of contextual influences in studying aspirations of rural youth.

Additionally, this study pays particular attention to gender differences regarding predictors of aspirations, as previous research suggests there are differences in the ways rural women and men conceptualize and plan for future education and employment. The study sought to illuminate whether certain individual, familial, geographic, or economic aspects were more predictive of the educational and occupational aspirations of rural women and men.

Accordingly, we posited the following research questions; (a) Are there gender differences in rural adolescents' educational and occupational aspirations? (b) Are there gender differences in factors that explain rural 
adolescents' educational aspirations and nontraditionality of occupational aspirations? And, (c) What is the relative influence of key motivation variables when controlling for individual characteristics, perceived family influence, and community characteristics?

\section{Method}

\subsection{Overview of Rural High School Aspirations Study}

The current study is part of a broader investigation to examine students' adjustment and postsecondary aspirations in rural high schools throughout the United States.

\subsubsection{Sample}

The total sample included 8,754 rural high school students in Grades 9 to 12 . Youth were recruited from 73 randomly selected schools in 34 states; $89 \%$ of the schools were from rural urban-centric locale codes $(41,42 \&$ $43)$ and $11 \%$ were from small small-town codes $(31,32 \& 33)$. Fifty percent of the sample attended schools in rural remote locations. Thirty-six schools had $40 \%$ or more students who were eligible to receive free- or reduced-lunch. Two subsamples of students were used for Study 1 and Study 2. Study 1 included 5,360 students and Study 2 included 3,535 students.

\subsubsection{Data Collection}

Recruitment and consenting procedures adhered to the participating school districts' local policies already in place and administrative regulations. Data for the current investigations were collected from the student and teacher surveys. The student instrument consisted of a paper and pencil questionnaire administered on-site by a team of trained researchers. Student surveys were group-administered in a common space on the school campus (e.g., cafeteria); the survey included 50 rating-scale and open-ended items to assess youth's socioeconomic status, academic progress, family and peer relations, aspirations and plans for the future, high school experiences, extracurricular activities, achievement-related motivation (i.e., perceptions of competence and school valuing), and educational and occupational barriers. For each participating student, first-period teachers completed a brief survey. The survey, completed for individual students, was composed of five items to parallel the student survey, and in addition, included items to assess academic progress, support services, and educational and occupational aspirations. It also included a scale to assess behavioral characteristics of the individual student.

\subsubsection{Definition and Construction of Analytic Variables}

The outcome measures in this study were educational aspirations and occupational aspirations. Educational aspirations were based on students' answer to a question of "how far in school would you most like to go?" The response options given were: 1 = less than high school graduation; 2 = high school graduation or GED only; $3=$ attend or complete a 2-year school course in a community college, occupational, or trade school; $4=$ attend college, but not complete a 4 -year degree; 5 = graduate from college; $6=$ obtain a master's degree or equivalent; $7=$ obtain a Ph.D., M.D., or other advanced degree; and $8=$ don't know. These above response options were then collapsed into four groups with the exclusion of the "don't know" category: (a) less than high school or high school diploma, (b) some college, (c) four-year degree, and (d) advanced/professional degree. Based on prior research (e.g., Blackwell \& McLaughlin, 1999), we treated educational aspirations as a continuous variable by transforming it into years of schooling (e.g., $2=12,7=22$ ). Occupational aspirations were based on the students' answer to this open-ended question: "What kind of job or occupation will you most like to have at age 30?" The research team standardized responses using the Standard Occupational Classification (SOC) numeric coding structure (U.S. Bureau of Labor Statistics, 2000). The nontraditionality of career choice was based on the percentage of the opposite gender employed in a desired occupation (U.S. Bureau of Labor Statistics, 2009) and was treated as a continuous variable with higher scores representing greater nontraditionality (e.g., Flores Navarro, Smith, \& Ploszaj, 2006). For example, a girl aspiring to the nursing profession would be assigned a score 12 (the percent of male workers employed this occupation), suggesting a low degree of nontraditionality. A boy aspiring to nursing would be assigned a score of 88 (the complement) suggesting a high degree of nontraditionality.

The independent variables included measures to assess key contextual influences on youth's educational and occupational aspirations. For Study 1, we included the student characteristics (a) race/ethnicity, (b) grade-level, (c) rural identity, (d) positive perception of economic opportunity in home community, and (e) residential aspirations. For school characteristics, we included (a) percent free lunch, (b) pupil-teacher ratio, and (c) school location: rural (vs. town). For family characteristics, we included (a) family economic hardship, (b) parental education, (c) two-parent family, (d) family size, (e) parent respect and identification, and (f) parental expectations for child's college education. For schooling experience characteristics, we included (a) college 
preparatory program (vs. other program), (b) retention (vs. no retention), (c) achievement, (d) postsecondary preparation, (e) academic self-concept, (f) school valuing, (g) school belonging, (h) breadth of activity involvement, (i) teacher's educational expectation for the student, and (j) teacher's assessment of social development of the student.

For Study 2, the focus was on explaining occupational aspirations. For this study, we broadened the focus to not only to include the student and familial variables described above, but also community characteristics and perceptions of economic opportunity. For community characteristics, we included (a) distance from school location to mid-sized city, and (b) level of community poverty. For community influence, we included (a) rural identity, (b) positive perception of economic opportunity at home communities, and (c) community obligation. Although important, the school-related experiences included as part of Study 1 were not included in Study 2. This exclusion was based on prior sociological studies emphasizing the role of familial and economic conditions on youth's occupational aspirations (e.g., Chenoweth \& Galliher, 2004; Crockett et al., 2000; Elder \& Conger, 2000). Please see the appendix for detailed descriptions of these variables.

\subsection{Analytic Plan}

Due to the fact that participating students were nested in schools, an unconditional hierarchical linear model was initially estimated (Raudenbush \& Bryk, 2002). Results indicated that only 3\% of the variance in rural youth's educational aspirations was attributable to the school-level and only $0.8 \%$ of observed variance in teenagers' career choice nontraditionality was attributable to school-level differences. These results suggest that the use of hierarchical linear modeling (HLM) offered little advantages over ordinary least squares (OLS) regression.

To address the research questions guiding this study, we ran several OLS analyses. For study 1, student, family and community background characteristics were entered first, followed by school characteristics, and finally, schooling experiences. For Study 2, student and community background characteristics were entered first, followed by family factors, and finally, community factors. OLS analyses were run separately for rural boys and girls. Follow-up analyses examined differences in the relative strength of individual, family, community, and school influences on rural youth's aspirations for the future.

\section{Results}

Results of Study 1 and Study 2 are presented separately; we first examine gender differences in educational aspirations and then we present findings from examining gender differences in aspirations for nontraditional careers.

\subsection{Gender Differences in the Educational Aspirations of Rural Youth (Study 1)}

Analyses included students who responded to the educational aspirations question on the survey (i.e., How far in school would you most like to go?). Students who did not respond or responded "don't know" were eliminated from the analyses. We excluded Asian Americans and youth who did not provide demographic background information because of small sample size. The final analytic sample consisted of 5,360 students in 64 schools and 30 states. White students were the largest racial ethnic group (73.7\%), followed by Hispanics or Latinos (12.9\%), African Americans (8.8\%), and Native Americans (4.6\%). At the time of the survey $28 \%$ were 9th graders, $27 \%$ were 10 th graders, and $25 \%$ were 11 th graders, and $20 \%$ were 12 th graders.

\subsubsection{Descriptive Statistics}

Table 1 presents the descriptive statistics for students' educational aspirations among the subsample $(n=5,360)$. As shown, girls desired to attain more schooling (17.3 years) than boys (16.4 years), and this difference was statistically significant $(p<.001)$. In addition, for this sample, girls reported higher parental expectations for college education than did boys. Additionally, boys reported more positive perceptions of economic opportunities in their home communities than girls, and boys also reported a higher attachment to their rural background and community (i.e., rural identity) and a higher desire to live in the same home state as adults.

In terms of schooling experiences, a relatively higher percentage of rural girls reported enrollment in a college preparatory programs compared to rural boys. Girls also reported higher levels of academic achievement, postsecondary preparation, and school valuing. Although boys reported a higher level of academic self-concept than girls, gender differences in teacher expectations for future educational attainment favored girls. In terms of negative schooling experiences, a higher percentage of boys reported encountering grade retention during their schooling. 
Table 1 . Study 1 descriptive statistics of variables used in the analysis by gender

\begin{tabular}{|c|c|c|c|c|c|c|}
\hline & \multicolumn{2}{|c|}{ Boys } & \multicolumn{2}{|c|}{ Girls } & \multicolumn{2}{|c|}{ Total } \\
\hline Number of cases & 2,570 & & 2,790 & & 5,360 & \\
\hline \multicolumn{7}{|l|}{ Dependent variable } \\
\hline Educational aspirations (years of education) ${ }^{* * *}$ & 16.4 & $(2.7)$ & 17.3 & $(2.7)$ & 16.9 & $(2.7)$ \\
\hline \multicolumn{7}{|l|}{ Independent variables } \\
\hline \multicolumn{7}{|l|}{ Family characteristics } \\
\hline Economic hardship & 1.8 & $(.9)$ & 1.8 & $(.9)$ & 1.8 & $(.9)$ \\
\hline Parental education** & 13.8 & $(2.9)$ & 13.6 & $(2.8)$ & 13.7 & $(2.9)$ \\
\hline Two-parent family (\%) & 58.6 & & 58.5 & & 58.5 & \\
\hline Family size** & 2.8 & $(1.7)$ & 2.9 & $(1.7)$ & 2.9 & $(1.7)$ \\
\hline Parent respect and identification & 4.4 & $(1.2)$ & 4.3 & $(1.2)$ & 4.4 & $(1.2)$ \\
\hline Parental expectations for child's college education*** & 4.6 & $(1.6)$ & 4.8 & $(1.5)$ & 4.7 & $(1.5)$ \\
\hline
\end{tabular}

\section{Student characteristics}

Race/ethnicity (\%)

White

Black

$\begin{array}{llll}73.4 & 74.0 & & 73.7 \\ 9.2 & 8.4 & & 8.8 \\ 12.3 & 13.3 & & 12.9 \\ 5.0 & 4.3 & 4.6 \\ 2.4 & (1.1) 2.4 & (1.1) & 2.4 \\ 3.0 & (1.2) 2.9 & (1.2) & 3.0 \\ 3.1 & (1.1) 2.9 & (1.1) & 3.0 \\ & & & \\ 39.5 & 34.7 & & 37.0 \\ 30.1 & 30.1 & & 30.1 \\ 30.5 & 35.2 & & 32.9\end{array}$

\section{School Characteristics}

Proportion of students receiving free lunch

Pupil-teacher ratio

School location: rural (\%)

\begin{tabular}{|c|c|c|c|}
\hline 4 & $(0.2) 0.4$ & $(.2)$ & 0.4 \\
\hline 13.9 & (3.3) 13.9 & (3.2) & 13.9 \\
\hline & 82.4 & & 82.5 \\
\hline
\end{tabular}

Residential Aspirations (\%)

Home state

Another state

Have not thought or decided

82.

82.4

82.5

Schooling experiences

College prep program $(\%) * *$

$\begin{array}{lllll}16.0 & & 19.3 & & 17.7 \\ 19.2 & & 13.3 & & 16.1 \\ 6.0 & (1.6) & 6.5 & (1.5) & 6.3 \\ 2.1 & (.7) & 2.2 & (.7) & 2.1 \\ 5.1 & (1.1) & 5.0 & (1.0) & 5.0 \\ 4.5 & (1.0) & 4.8 & (.9) & 4.6\end{array}$

Achievement***

Postsecondary preparation***

Academic self-concept*

School valuing $* * *$

$4.5 \quad(1.0) 4.8$ 
School belonging

Breadth of activity involvement

Teacher's educational expectation for the student***

Teacher's assessment of social development of the student***

$\begin{array}{lllll}3.6 & (.9) & 3.6 & (.8) & 3.6 \\ 4.3 & (4.3) & 4.1 & (3.4) & 4.2 \\ 14.4 & (2.3) & 14.7 & (2.2) & 14.6 \\ 4.8 & (.9) & 5.0 & (.9) & 4.9\end{array}$

(.9)

Note. The numbers are mean and the numbers in parentheses are standard deviations unless percentages are noted.

T-test and Pearson chi-square test were conducted for continuous and categorical variables, respectively.

$* * * \mathrm{p}<.001, * * \mathrm{p}<.01, * \mathrm{p}<.05$ (two-tailed tests)

\subsubsection{Predictors of Educational Aspirations by Gender}

The second research question focused on examining individual and contextual predictors of gender differences in educational and occupational aspirations. We conducted separate OLS regression analyses for boys and girls in the sample. We highlight key predictors of educational aspirations from the full model (Model 4) for each subsample.

Boys. Table 2 presents OLS regression results for rural boys. Among family background variables, parental education, parent respect and identification, and parental aspirations for child's college education were significantly related to boys' educational aspirations. All student variables included in this analysis were significantly related to educational aspirations. Hispanic high school boys, on average, desired to attain more schooling than their White counterparts. Grade level was negatively associated with educational aspirations. Rural identity, positive perception of economic opportunity in home communities, and preferences to live in the same state were also negatively associated with educational aspirations. All schooling experiences except for school belonging, breadth of activity involvement, and teacher's assessment of interpersonal competence significantly predicted educational aspirations among rural boys. Grade retention was negatively associated with educational aspirations, whereas higher levels of academic achievement, postsecondary education preparation, academic self-concept, and school valuing were associated with higher levels of educational aspirations. Positive teacher expectations for future education were also associated with higher educational aspirations for boys.

Table 2. Study 1 coefficients from OLS regression of educational aspirations on selected family (model 1), student (model 2), school (model 3) characteristics, and schooling experiences (model 4) for boys $(\mathrm{n}=2,570)$

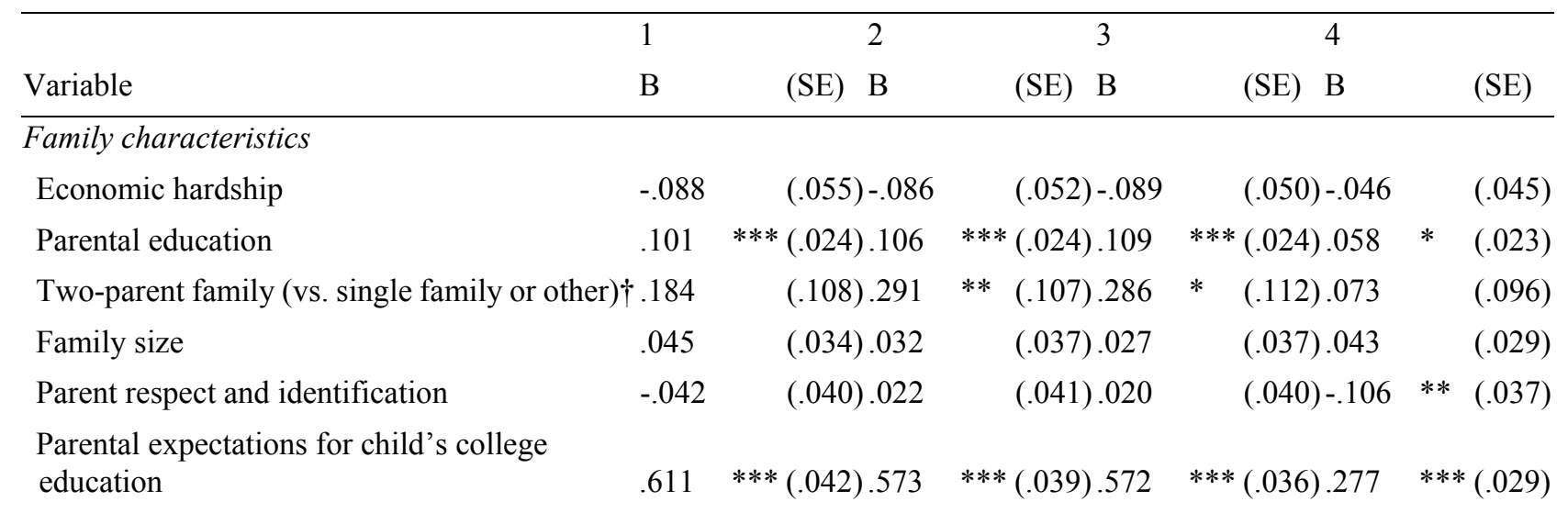

\section{Student characteristics}

Race/ethnicity (White omitted)

\begin{tabular}{|c|c|c|c|c|c|}
\hline Black & .381 & $(.258) .233$ & $(.269) .207$ & & $(.230)$ \\
\hline Hispanic & .148 & $(.174) .162$ & $(.200) .426$ & $*$ & $(.190)$ \\
\hline Native Americans & -.211 & $(.158)-.271$ & $(.154) .053$ & & $(.148)$ \\
\hline Grade level $\dagger$ & .016 & $(.046) .019$ & $(.045)-.129$ & $* *$ & $(.046)$ \\
\hline Rural identity & .024 & $(.045) .023$ & $(.045)-.116$ & $* *$ & $(.039)$ \\
\hline
\end{tabular}


Positive perception of economic opportunity in home community

$\begin{array}{llll}-.267 & * * *(.055)-.261 & * * *(.055)-.158 & * * *(.039) \\ .653 & * * *(.106) .674 & * * *(.110) .438 & * * *(.096) \\ .598 & * * *(.100) .606 & * * *(.101) .333 & * * *(.078)\end{array}$

Residential Aspirations (Home state omitted)

Another state

\section{School Characteristics}

Free lunch \%

$.336 \quad(.461) .092$

Pupil-teacher ratio

School location: rural (vs. town)

$.017 \quad(.018) .028$

$.266 \quad(.234) .157$

\section{Schooling experiences}

College prep program (vs. other program)

$.547 * *(.155)$

Retention (vs. no retention)

$-.191 *(.092)$

Achievement

$.159 * * *(.032)$

Postsecondary preparation

$.452 * * *(.068)$

Academic self-concept

$.309 * * *(.048)$

School valuing

$.395 * * *(.050)$

School belonging

Breadth of activity involvement

$-.009$

Teacher's educational expectation for the studenti

Teacher's assessment of social development of the student

Intercept

$R$-square .166

.196

.198

$R$-square change

$.029 * * *$

.0023

Note: $\mathrm{B}=$ unstandardized coefficients, $\mathrm{SE}=$ standard errors.

$* * * \mathrm{p}<.001,{ }^{*} \mathrm{p}<<.01, * \mathrm{p}<.05$ (two-tailed tests)

$\dagger$ Differences in the magnitude of the coefficient for this variable between boys and girls were statistically significant at .01 level.

Girls. Table 3 presents OLS regression results for rural girls. Among family background variables, family structure and parental expectations for child's college education were significant predictors of educational aspirations for girls. Parental education, parental respect and identification, Hispanic background, and positive perceptions of economic opportunities, all of which were significant predictors of educational aspirations for boys, were nonsignificant predictors for girls. Among schooling experience variables, curricular track, achievement, postsecondary preparation, academic self-concept, school valuing, and teacher's educational expectation for the student were significant predictors of educational aspirations among rural girls. 
Table 3. Study 1 coefficients from OLS regression of educational aspirations on selected family (model 1), student (model 2), school (model 3) characteristics, and schooling experiences (model 4) for girls $(\mathrm{n}=2,790)$

\begin{tabular}{|c|c|c|c|c|c|c|c|c|c|c|c|c|}
\hline \multirow[b]{2}{*}{ Variable } & \multicolumn{3}{|l|}{1} & \multicolumn{3}{|l|}{2} & \multicolumn{3}{|l|}{3} & \multicolumn{3}{|l|}{4} \\
\hline & $\mathrm{B}$ & & (SE) & B & & (SE) & $\mathrm{B}$ & & (SE) & B & & (SE) \\
\hline \multicolumn{13}{|l|}{ Family characteristics } \\
\hline Economic hardship & -.098 & & .052 & -.106 & $*$ & .053 & -.105 & & .053 & -.047 & & .054 \\
\hline Parental education & .045 & $*$ & .017 & .042 & $*$ & .017 & .041 & $*$ & .016 & .012 & & .016 \\
\hline $\begin{array}{l}\text { Two-parent family (vs. single family or } \\
\text { other) } \dagger\end{array}$ & -.249 & & .125 & -.169 & & .132 & -.168 & & .131 & -.345 & $* *$ & .111 \\
\hline Family size & -.047 & & .027 & -.047 & & .028 & -.046 & & .027 & -.027 & & .027 \\
\hline Parent respect and identification & .108 & $* *$ & .038 & .128 & $* *$ & .042 & .128 & $* *$ & .042 & -.058 & & .041 \\
\hline $\begin{array}{l}\text { Parental expectations for child's college } \\
\text { education }\end{array}$ & .551 & $* * *$ & .033 & .547 & $* * *$ & .033 & .548 & $* * *$ & .033 & .323 & & $* .030$ \\
\hline \multicolumn{13}{|l|}{ Student characteristics } \\
\hline \multicolumn{13}{|l|}{ Race/ethnicity (White omitted) } \\
\hline Black & & & & .389 & & .224 & .453 & & .278 & .468 & & .235 \\
\hline Hispanic & & & & -.085 & & .203 & -.093 & & .200 & .200 & & .187 \\
\hline Native Americans & & & & -.065 & & .268 & -.041 & & .281 & .142 & & .238 \\
\hline Grade level $\dagger$ & & & & -.082 & & .041 & -.085 & $*$ & .041 & -.270 & & $* .042$ \\
\hline Rural identity & & & & .048 & & .042 & .051 & & .043 & -.123 & $* *$ & .036 \\
\hline $\begin{array}{l}\text { Positive perception of economic opportun } \\
\text { community }\end{array}$ & in hom & & & -.115 & $*$ & .057 & -.117 & $*$ & .056 & -.077 & & .048 \\
\hline \multicolumn{13}{|l|}{ Residential Aspirations (Home state omitted) } \\
\hline Another state & & & & .618 & $* * *$ & .113 & .610 & $* * *$ & .117 & .444 & & $* .110$ \\
\hline Have not thought or decided & & & & .534 & $* * *$ & .110 & .531 & $* * *$ & .111 & .422 & & $* .103$ \\
\hline \multicolumn{13}{|l|}{ School characteristics } \\
\hline Free lunch \% & & & & & & & -.099 & & .466 & -.031 & & .453 \\
\hline Pupil-teacher ratio & & & & & & & -.008 & & .018 & -.005 & & .018 \\
\hline School location: rural (vs. town) & & & & & & & -.099 & & .193 & -.158 & & .212 \\
\hline \multicolumn{13}{|l|}{ Schooling experiences } \\
\hline College prep program (vs. other program) & & & & & & & & & & .376 & $*$ & .168 \\
\hline Retention (vs. no retention) & & & & & & & & & & -.274 & & .149 \\
\hline Achievement & & & & & & & & & & .194 & & $* .033$ \\
\hline Postsecondary preparation & & & & & & & & & & .361 & & $* .074$ \\
\hline Academic self-concept & & & & & & & & & & .328 & & $* .061$ \\
\hline School valuing & & & & & & & & & & .407 & & $* .077$ \\
\hline School belonging & & & & & & & & & & .149 & & .078 \\
\hline Breadth of activity involvement & & & & & & & & & & .017 & & .013 \\
\hline $\begin{array}{l}\text { Teacher's educational expectation for the } \\
\text { student } \dagger\end{array}$ & & & & & & & & & & .146 & & $* .030$ \\
\hline $\begin{array}{l}\text { Teacher's assessment of social developme } \\
\text { student }\end{array}$ & of the & & & & & & & & & -.016 & & .064 \\
\hline Intercept & 14.04 & $5 * * *$ & .326 & 13.965 & $* * *$ & .398 & 14.209 & $9 * * *$ & .490 & 8.951 & & $* .582$ \\
\hline$R$-square & .108 & & & .124 & & & .124 & & & .254 & & \\
\hline$R$-square change & - & & & $.015^{* *}$ & & & .000 & & & $.131 * *$ & & \\
\hline
\end{tabular}


Note: $\mathrm{B}=$ unstandardized coefficients, $\mathrm{SE}=$ standard errors.

$$
* * * \mathrm{p}<.001,{ }^{* *} \mathrm{p}<.01,{ }^{*} \mathrm{p}<.05 \text { (two-tailed tests) }
$$

$\dagger$ Differences in the magnitude of the coefficient for this variable between boys and girls were statistically significant at .01 level.

\subsubsection{Summary of Educational Aspirations by Gender}

Consistent with recent research on rural youth, the results indicated that rural girls reported higher educational aspirations than their male counterparts. Whereas the results indicated important gender differences in youth's perceptions of economic opportunities, parental educational expectations, residential preferences, and schooling experiences also mattered. Compared to boys, girls had higher levels of academic achievement, postsecondary education preparation, and school valuing, and these ratings were positively related to future educational aspirations for both boys and girls. Teachers held higher educational expectations for rural girls than boys, and teacher expectations were more strongly related to boys' than girls' postsecondary educational aspirations. Boys were also more likely than girls to experience early grade retention in school, which predicted future educational aspirations for boys. With all other variables controlled, including school characteristics (e.g., poverty status, size, and rural locale), schooling experiences explained additional variance in educational aspirations for both boys $(18 \%)$ and girls $(13 \%)$ in this rural sample.

\subsection{Gender Differences in Aspirations for Nontraditional Occupations (Study 2)}

In examining gender differences in nontraditionality of occupational aspirations, analyses included those students attending rural high schools (i.e., rural fringe, rural distant, and rural remote) and those who reported educational as well as occupational aspirations. We also excluded those students who answered "don't know" to the question asking about their educational and occupational aspirations (approximately $7 \%$ of the total rural sample). The final sample consisted of 3,535 rural high school students (1,975 girls and 1,560 boys) distributed across 65 schools and 32 states. White students were the largest racial/ethnic group (74.2\%), followed by multiracial (9.7\%), Hispanics or Latinos (7.1\%), African Americans (5.2\%), and Native Americans (3.8\%). At the time of the study, approximately $21.4 \%$ of the students were ninth graders, $26.4 \%$ were $10^{\text {th }}$ graders, $27.2 \%$ were $11^{\text {th }}$ graders, and $25.0 \%$ were $12^{\text {th }}$ graders.

\subsubsection{Descriptive Statistics}

Table 4 presents descriptive statistics for Study 2 variables $(n=3,535)$. Initial analyses revealed gender differences in nontraditionality of occupational aspirations. Results indicated that rural girls aspired to more nontraditional careers than did their male peers (nontraditional scores $=.40$ vs. .20 , respectively; $p<.001$ ). In terms of predictor variables, as reported for Study 1, significant gender differences, favoring girls, were found for both maternal and paternal educational expectations. Girls also reported a stronger family obligation than did boys. For this subsample of rural youth, boys, on the other hand, reported more positive perceptions of local economic opportunities and a greater desire to live in their home state, when compared to their female peers (see Table 4). 
Table 4. Study 2 descriptive statistics of variables used in the analysis by gender

\begin{tabular}{|c|c|c|c|c|c|c|}
\hline & Boys & & Girls & & Total & \\
\hline Number of cases & 1,560 & & 1,975 & & 3,535 & \\
\hline \multicolumn{7}{|l|}{ Dependent variable } \\
\hline Career choice nontraditionality $(\%)^{* * *}$ & 28.4 & $(21.5)$ & 40.9 & (24.0) & 35.4 & (23.7) \\
\hline \multicolumn{7}{|l|}{ Independent variables } \\
\hline \multicolumn{7}{|l|}{ Student characteristics } \\
\hline \multicolumn{7}{|l|}{ Race/ethnicity (\%) } \\
\hline White & 74.1 & & 74.3 & & 74.2 & \\
\hline Multiracial & 9.7 & & 9.7 & & 9.7 & \\
\hline Hispanic & 7.6 & & 6.6 & & 7.1 & \\
\hline Black & 4.7 & & 5.6 & & 5.2 & \\
\hline Native Americans & 3.9 & & 3.7 & & 3.8 & \\
\hline Grade level & 2.6 & $(1.1)$ & 2.6 & $(1.1)$ & 2.6 & (1.1) \\
\hline Achievement*** & 6.3 & $(1.6)$ & 6.7 & (1.4) & 6.5 & $(1.5)$ \\
\hline \multicolumn{7}{|l|}{ Community characteristics } \\
\hline Distance from school to closest mid-size city (miles) & 195.7 & $(150.2)$ & 187.7 & (142.5) & 191.2 & $(145.9)$ \\
\hline Community poverty $(\%)^{* *}$ & 17.2 & $(5.3)$ & 17.7 & $(5.5)$ & 17.5 & (5.4) \\
\hline \multicolumn{7}{|l|}{ Family characteristics } \\
\hline Economic hardship** & 1.7 & $(.9)$ & 1.8 & $(.9)$ & 1.7 & $(.9)$ \\
\hline Two-parent family $(\%)^{* *}$ & 64.2 & & 59.8 & & 61.8 & \\
\hline Mother's education** & 13.7 & $(2.3)$ & 13.5 & $(2.2)$ & 13.6 & $(2.3)$ \\
\hline Father's education** & 13.3 & (2.3) & 13.1 & $(2.2)$ & 13.2 & $(2.2)$ \\
\hline Mother's expectations of child's college education ${ }^{* * *}$ & 4.7 & $(1.6)$ & 5.0 & $(1.4)$ & 4.9 & $(1.5)$ \\
\hline Father's expectations of child's college education ${ }^{* * *}$ & 4.6 & $(1.7)$ & 4.9 & $(1.6)$ & 4.8 & (1.6) \\
\hline Parent respect and identification & 4.4 & $(1.2)$ & 4.3 & $(1.2)$ & 4.4 & $(1.2)$ \\
\hline Family obligation $* * *$ & 3.5 & $(1.0)$ & 3.7 & $(1.0)$ & 3.6 & $(1.0)$ \\
\hline \multicolumn{7}{|l|}{ Community influences } \\
\hline Rural identity & 3.7 & (1.4) & 3.6 & (1.4) & 3.6 & (1.4) \\
\hline Positive percept. of econ. opportunity in home community $* * *$ & 3.5 & $(1.4)$ & 3.3 & $(1.2)$ & 3.4 & $(1.2)$ \\
\hline Community obligation $* * *$ & 3.9 & $(1.0)$ & 4.1 & (1.0) & 4.0 & (1.0) \\
\hline
\end{tabular}

Note. The numbers are mean and the numbers in parentheses are standard deviations unless percentages are noted. T-test and Pearson chi-square test were conducted for continuous and categorical variables, respectively.

$* * * \mathrm{p}<.001,{ }^{* *} \mathrm{p}<.01,{ }^{*} \mathrm{p}<.05$ (two-tailed tests)

\subsubsection{Predictors of Aspirations for Nontraditional Occupations by Gender}

For this analysis we included student, community, and family characteristics. To examine differences in predictors of nontraditionality of occupational aspirations, we conducted separate OLS regression analyses for boys and girls in the subsample. We highlight key predictors of nontraditionality in occupational aspirations from the full model (model 4) by gender.

Boys. Table 5 presents OLS regression results for rural boys. The full model explained $8 \%$ of the variance in boys' nontraditionality of occupational aspirations was explained by student, family, and community variables. Results indicated that the strongest overall predictor of nontraditionality for boys was student achievement. Boys with higher levels of achievement were more likely to aspire to nontraditional occupations. In addition, boys 
who thought their mother or female guardian would be disappointed if they did not graduate from college also were more likely to aspire to nontraditional occupations. Boys with higher levels of rural identity were less likely to aspire to nontraditional occupations. Boys who self-reported their race/ethnicity as multiracial and boys who were in the upper grades were slightly more likely to aspire to nontraditional occupations. Finally, boys who lived farther from metropolitan areas were slightly less likely to aspire to nontraditional occupations.

Table 5. Study 2 standardized coefficients from OLS regression of career choice nontraditionality on selected student (model 1) and community (model 2) characteristics, perceived family (model 3) and perceived community (model 4 ) factors for boys $(\mathrm{n}=1,560)$

\begin{tabular}{|c|c|c|c|c|c|c|c|c|}
\hline & 1 & & 2 & & 3 & & 4 & \\
\hline Variable & B & & $\mathrm{B}$ & & B & & $\mathrm{B}$ & \\
\hline \multicolumn{9}{|l|}{ Student characteristics } \\
\hline \multicolumn{9}{|l|}{ Race/ethnicity (\%) } \\
\hline Black & .02 & & .02 & & .01 & & .00 & \\
\hline Hispanic & .01 & & .01 & & .02 & & .01 & \\
\hline Native Americans & .00 & & .00 & & .00 & & .00 & \\
\hline Multiracial & .07 & & .07 & $* *$ & .06 & $*$ & .06 & $*$ \\
\hline Grade level & .05 & $* * *$ & .05 & $*$ & .06 & * & .06 & * \\
\hline Achievement & .17 & $*$ & .18 & $* * *$ & .15 & $* * *$ & .15 & $* * *$ \\
\hline \multicolumn{9}{|l|}{ Community characteristics } \\
\hline $\begin{array}{l}\text { Distance from school to closest mid-size } \\
\text { city (miles) }\end{array}$ & & & -.05 & & -.06 & * & -.05 & $*$ \\
\hline Community poverty (\%) & & & .01 & & .01 & & -.01 & \\
\hline \multicolumn{9}{|l|}{ Family characteristics } \\
\hline Economic hardship & & & & & .06 & * & .05 & \\
\hline Two-parent family (\%) & & & & & -.01 & & .01 & \\
\hline Mother's education & & & & & .00 & & .00 & \\
\hline Father's education & & & & & .06 & $*$ & .05 & \\
\hline $\begin{array}{l}\text { Mother's expectations of child's college } \\
\text { education }\end{array}$ & & & & & .13 & $* *$ & .13 & $* *$ \\
\hline $\begin{array}{l}\text { Father's expectations of child's college } \\
\text { education }\end{array}$ & & & & & .00 & & .01 & \\
\hline Parent respect and identification & & & & & -.04 & & -.01 & \\
\hline Family obligation & & & & & .00 & & .01 & \\
\hline \multicolumn{9}{|l|}{ Community influence } \\
\hline Rural identity & & & & & & & -.13 & $* * *$ \\
\hline $\begin{array}{l}\text { Positive perception of economic } \\
\text { opportunity home community }\end{array}$ & & & & & & & -.02 & \\
\hline Community obligation & & & & & & & -.01 & \\
\hline$R$-square & .038 & & .040 & & .064 & & .079 & \\
\hline$R$-square change & - & & .003 & & .024 & $* * *$ & .015 & $* * *$ \\
\hline
\end{tabular}

Note: $\mathrm{B}=$ standardized coefficients.

${ }^{* * *} \mathrm{p}<.001,{ }^{* *} \mathrm{p}<.01,{ }^{*} \mathrm{p}<.05$ (two-tailed tests)

$\dagger$ Differences in the magnitude of the coefficient for this variable between boys and girls were statistically significant at .01 level. 
Girls. Table 6 presents OLS regression results for rural girls. The full model explained $4 \%$ of the variance in girls' nontraditionality of occupational aspirations. Results indicate that the strongest predictor of nontraditionality of occupational aspirations for girls was grade level. Unlike boys, girls in the upper grades were less likely to aspire to nontraditional occupations. Student achievement was the next strongest predictor of nontraditionality. Girls with higher levels of achievement were more likely to aspire to nontraditional occupations. Girls who self-reported their race/ethnicity as multiracial were slightly more likely to aspire to nontraditional occupations. Finally, girls with higher levels of rural identity were slightly less likely to aspire to nontraditional occupations.

Table 6. Study 2 standardized coefficients from OLS regression of career choice nontraditionality on selected student (model 1) and community (model 2) characteristics, perceived family (model 3) and perceived community (model 4) factors for girls $(\mathrm{n}=1,975)$

\begin{tabular}{|c|c|c|c|c|c|c|c|c|}
\hline \multirow[b]{2}{*}{ Variable } & \multicolumn{2}{|l|}{1} & \multicolumn{2}{|l|}{2} & \multicolumn{2}{|l|}{3} & \multicolumn{2}{|l|}{4} \\
\hline & \multicolumn{2}{|l|}{ B } & \multicolumn{2}{|l|}{ B } & \multicolumn{2}{|l|}{ B } & \multicolumn{2}{|l|}{ B } \\
\hline \multicolumn{9}{|l|}{ Student characteristics } \\
\hline \multicolumn{9}{|l|}{ Race/ethnicity (\%) } \\
\hline Black & .03 & & .02 & & .02 & & .02 & \\
\hline Hispanic & .00 & & -.01 & & .00 & & .00 & \\
\hline Native Americans & .00 & & .00 & & .00 & & .00 & \\
\hline Multiracial & .06 & $* *$ & .06 & $* *$ & .06 & $*$ & .05 & $*$ \\
\hline Grade level & -.12 & $* * *$ & -.11 & $* * *$ & -.12 & $* * *$ & -.12 & $* * *$ \\
\hline Achievement & .10 & $* * *$ & .10 & $* * *$ & .10 & $* * *$ & .11 & $* * *$ \\
\hline \multicolumn{9}{|l|}{ Community characteristics } \\
\hline $\begin{array}{l}\text { Distance from school to closest mid-size } \\
\text { city (miles) }\end{array}$ & & & -.01 & & -.01 & & -.01 & \\
\hline Community poverty (\%) & & & .02 & & .02 & & .01 & \\
\hline \multicolumn{9}{|l|}{ Family characteristics } \\
\hline Economic hardship & & & & & .03 & & .02 & \\
\hline Two-parent family (\%) & & & & & -.05 & & -.04 & \\
\hline Mother's education & & & & & -.01 & & -.01 & \\
\hline Father's education & & & & & .51 & & .05 & \\
\hline $\begin{array}{l}\text { Mother's expectations of child's college } \\
\text { education }\end{array}$ & & & & & .00 & & .00 & \\
\hline $\begin{array}{l}\text { Father's expectations of child's college } \\
\text { education }\end{array}$ & & & & & .04 & & .04 & \\
\hline Parent respect and identification & & & & & -.02 & & .00 & \\
\hline Family obligation & & & & & -.01 & & .00 & \\
\hline \multicolumn{9}{|l|}{ Community influence } \\
\hline Rural identity & & & & & & & -.06 & $*$ \\
\hline $\begin{array}{l}\text { Positive perception of economic } \\
\text { opportunity in home community }\end{array}$ & & & & & & & -.04 & \\
\hline Community obligation & & & & & & & -.03 & \\
\hline$R$-square & .03 & & .03 & & .03 & & .04 & \\
\hline & - & & .001 & & .007 & $*$ & .006 & $* *$ \\
\hline
\end{tabular}

Note: $\mathrm{B}=$ standardized coefficients.

$* * * \mathrm{p}<.001,{ }^{* *} \mathrm{p}<.01,{ }^{*} \mathrm{p}<.05$ (two-tailed tests)

$\dagger$ Differences in the magnitude of the coefficient for this variable between boys and girls were statistically significant at .01 level. 


\subsubsection{Summary of Aspirations for Nontraditional Occupations by Gender}

This study indicated that rural girls were more likely than rural boys to aspire to nontraditional careers. Nontraditional occupational aspirations may provide rural adolescent girls with greater flexibility in a changing labor market. Along with schooling influences (i.e., access to college preparation programs), rural youth's perceptions of local economic opportunities and connections to their home communities were important predictors of occupational aspirations. Contrary to prior research (e.g., Elder \& Conger, 2000) gender differences in self-reports of family obligations was not a significant predictor for either group of rural youth. Although the results identified multiple predictors of nontraditional career choices for both gender groups, the specified variables accounted for only a small percentage of the variance ( $4 \%$ for girls and $8 \%$ for boys) in career choice nontraditionality. The findings suggest that influence of background, family, and local community factors may hold less relevance for today's rural adolescents' career decision-making. Technological advancement and globalization also likely impact the formation of rural adolescents' self-conceptions, such as occupational identities (Arnett, 2002). Today's rural youth have greater access to media, which is a significant socialization agent. To the degree that technology connects youth to worldviews beyond that of their community, geographic isolation and proximal community influences may be less salient to career decision-making (Arnett, 2002; Jensen, 2003; Larson, 2002).

\section{Discussion}

Educational and occupational aspirations are important indicators of successful developmental outcomes. Research shows that aspirations influence later educational and occupational attainment and successful adaptation from adolescence into adulthood (Bandura et al., 2001; Beal \& Crockett, 2010; Eccles et al., 2004; Elder \& Conger, 2000; Schneider \& Stevenson, 1999). The current study utilized an ecological framework to highlight the several unique economic, geographic, and social features of rural communities that shape rural adolescents' educational and occupational outcomes (Crockett et al., 2000; Elder \& Conger, 2000). The results included rural U.S. adolescents from 73 high schools in 34 states within the United States. The results are clearly limited to youth within U.S. rural locales, but provide important evidence about the role of contextual factors in shaping youth's aspirations for the future.

Study results revealed important gender differences in rural adolescents' educational and occupational aspirations. Consistent with prior research of rural youth in the U.S. (Elder \& Conger, 2000; Chenoweth \& Galliher, 2004), rural girls, when compared to boys, aspired to higher levels of education, careers requiring more education, and nontraditional occupations for their gender. In terms of family influences, parental expectations for education had the strongest influence on all outcome measures examined. With family income controlled, few ethnic or racial differences in the aspiration measures emerged. However, lower educational and occupational aspirations were reported by youth with strong attachment to a rural lifestyle, more positive perceptions of local economic opportunities, and residential aspirations to remain close to their home community. Finally, consistent with expectancy-value motivation frameworks, self-reports of academic competence and school valuing (e.g., importance of school for future) were significant predictors of educational aspirations. These findings emerged with the influence of all other variables controlled, including family income, which is one of the strongest predictors of educational and occupational aspirations among rural youth. The study also identified unique contextual influences (e.g., residential aspirations, rural identity, and perceptions of economic opportunity) that need to be considered in studies of rural youth (see also Petrin et al., 2014).

Study results add to the growing body of research on rural youth and their educational trajectories (Byun et al., 2012; Griffin et al., 2010; Hutchins et al., 2012; Irvin et al., 2011; Meece et al., 2013) and have three major implications. First, the outmigration of youth from their home communities continues to be an issue of concern (Carr \& Keflas, 2009; Corbett, 2007; Petrin et al., 2014). The results of this current large-scale study in the U.S suggest that this outmigration pattern may continue. However, data reported elsewhere indicate that youth may leave their rural communities to gain education and skills but many plan to return and utilize those skills to better their communities (Farmer et al., 2006; Petrin et al., 2014). A second implication involves addressing the differences in educational and occupational aspirations for rural girls and boys. Ensuring that both girls and boys are exposed to a variety of occupational options and receive the same encouraging feedback is necessary for these students, who are often short-changed when it comes to school programming and resources (Irvin et al., 2011). Our study highlighted the important role of family members in influencing educational and occupational aspirations of rural adolescents, a finding that may be useful in addressing career- and college-preparation resources provided to both rural girls and boys. Third, the results of Study 1 emphasize the significant role of motivation variables in the schooling and developmental outcomes of rural adolescents. Future research efforts 
that look at rural students' aspirations and attainment should include motivation variables as important predictors.

\section{Acknowledgments}

This research was supported by funding from the Spencer Foundation (Reference Number 201300107) and the Institute of Education Sciences, U.S. Department of Education (Grant Number \#R305A04056).

\section{References}

Arnett, J. J. (2002). The psychology of globalization. American Psychologist, 57(10), 774-783. http://dx.doi.org/10.1037/0003-066X.57.10.774

Bandura, A. (1986). Social foundations of thought and action: A social cognitive theory. NJ: Prentice-Hall, Inc.

Bandura, A., Barbaranelli, C., Caprara, G. V., \& Pastorelli, C. (2001). Self-efficacy beliefs as shapers of children's aspirations and career trajectories. Child Development, 72(1), 187-206. http://dx.doi.org/10.1111/1467-8624.00273

Beal, S. J., \& Crockett, L. J. (2010). Adolescents' occupational and educational aspirations and expectations: Links to high school activities and adult educational attainment. Developmental Psychology, 46(1), 258-265. http://dx.doi.org/10.1037/a0017416

Blackwell, D. L., \& McLaughlin, D. K. (1999). Do rural youth attain their educational goals? Rural Development Perspectives, 13(3), 37-44.

Bronfenbrenner, U. (1977). Toward an experimental ecology of human development. American Psychologist, 32, 513-530. http://dx.doi.org/10.1037/0003-066X.32.7.513

Brown, D. L., \& Schafft, K. A. (2011). Rural people and communities in the 21st century. Cambridge, MA: Polity Press.

Byun, S. Y., Meece, J. L., \& Irvin, M. J. (2012). Rural-nonrural disparities in postsecondary educational attainment revisited. American Educational Research Journal, 49(3), 412-437. http://dx.doi.org/10.3102/0002831211416344

Carr, P. J., \& Kefalas, M. J. (2009). Hollowing out the middle: The rural brain drain and what it means for America. Beacon Press.

Chenoweth, E., \& Galliher, R. (2004). Factors influencing college aspirations of rural West Virginia high school students. Journal of Research in Rural Education, 19(2), 1-14. Retrieved from http://www.jrre.psu.edu/articles/19-2.pdf

Corbett, M. J. (2007). Learning to leave: The irony of schooling in a coastal community. Black Point, Nova Scotia: Fernwood Publishing.

Crockett, L. J., Shanahan, M. J., \& Jackson-Newsom, J. (2000). Rural youth: Ecological and life course perspectives. In. R. Montemayor (Ed.), Advances in adolescent development: Vol. 10. Adolescent diversity n ethnic, economic, and cultural contexts (pp. 43-74). Thousand Oaks, CA: Sage.

Dyk, P., \& Wilson, S. (1999). Family-based social capital considerations as predictors of attainments among $\begin{array}{llll}\text { Appalachian } \quad \text { youth. } & \text { Sociological } & \text { Inquiry, } & 69(3),\end{array}$ http://dx.doi.org/10.1111/j.1475682X.1999.tb00882.x

Eccles, J. S. (1987). Gender roles and women's achievement-related decisions. Psychology of Women Quarterly, 11(2), 135-172. http://dx.doi.org/10.1111/j.1471-6402.1987.tb00781.x

Eccles, J. S. (2007). Where are all of the women? In S. J. Ceci, \& W. M. Williams (Eds.), Why aren't more women in science? Top researchers debate the evidence (pp. 199-210). Washington, DC: American Psychological Association. http://dx.doi.org/10.1037/11546-016

Eccles, J., Brown, B. V., \& Templeton, J. (2008). A developmental framework for selecting indicators of well-being during the adolescent and young adult years. In B. V. Brown (Ed.), Key indicators of child and youth well-being (pp. 197-236). New York, NY: Lawrence Erlbaum Associates.

Eccles, J. S., Vida, M. N., \& Barber, B. (2004). The relation of early adolescents' college plans and both academic ability and task-value beliefs to subsequent college enrollment. Journal of Early Adolescence, 24(1), 63-77. http://dx.doi.org/10.1177/0272431603260919 
Eccles, J. S., Wigfield, A., \& Schiefele, U. (1998). Motivation to succeed. In W. Damon, \& N. Eisenberg (Eds.), Handbook of child psychology, $5^{\text {th }}$ edition, Vol. 3, Social, emotional, and personality development (pp. 1017-1095). New York: Wiley.

Elder, G. H., \& Conger, R. D. (2000). Children of the land: Adversity and success in rural America. Chicago: University of Chicago Press.

Farmer, T. W., Dadisman, D., Latendresse, S. J., Thompson, J., Irvin, M. J., \& Zhang, L. (2006). Educating out and giving back: Adults' conceptions of successful outcomes of African American high school students from impoverished rural communities. Journal of Research in Rural Education, 21(10), 1-12. Retrieved from http://www.jrre.psu.edu/articles/21-10.pdf

Flores, L. Y., Navarro, R. L., Smith, J. L., \& Ploszaj, A. M. (2006). Testing a model of nontraditional career choice goals with Mexican American adolescent men. Journal of Career Assessment, 14, 214-234. http://dx.doi.org/10.1177/1069072705283763

Frome, P. M., Alfeld, C. J., Eccles, J. S., \& Barber, B. L. (2006). Why don't they want a male-dominated job? An investigation of young women who changed their occupational aspirations. Educational Research and Evaluation, 12(4), 359-372. http://dx.doi.org/10.1080/13803610600765786

Griffin, D., Hutchins, B. C., \& Meece, J. L. (2011). Where do rural high school students go to find information about their futures? Journal of Counseling \& Development, 89, 172-181. http://dx.doi.org/10.1002/j.1556-6678.2011.tb00075.x

Hardré, P. L., Sullivan, D. W., \& Crowson, M. H. (2009). Student characteristics and motivation in rural high schools. Journal of Research in Rural Education, 24, 1-19. Retrieved from http://www.jrre.psu.edu/articles/24-16.pdf

Hektner, J. M. (1995). When moving up implies moving out: Rural adolescent conflict in the transition to adulthood. Journal of Research in Rural Education, 11, 3-14. Retrieved from http://www.jrre.psu.edu/articles/v11,n1,p3-14,Hektner.pdf

Hill, N. E., Castellino, D. R., Lansford, J. E., Nowlin, P., Dodge, K. A., Bates, J. E., \& Pettit, G. S. (2004). Parent academic involvement as related to school behavior, achievement, and aspirations: Demographic variations across adolescence. Child Development, 75(5), 1491-1509. http://dx.doi.org/10.1111/j.1467-8624.2004.00753.x

Hill, N. E., Ramirez C., \& Dumka L. E. (2003). Early adolescents' career aspirations: A qualitative study of perceived barriers and family support among low income, ethnically diverse adolescents. Journal of Family Issues, 24, 934-959. http://dx.doi.org/10.1177/0192513X03254517

Howley, C. W. (2006). Remote possibilities: Rural children's educational aspirations. Peabody Journal of Education, 81(2), 62-80. http://dx.doi.org/10.1207/S15327930pje8102_4

Hutchins, B. C., Meece, J. L., Byun, S. Y., \& Farmer, T. W. (2012). Planning for the future: An investigation of work-bound rural youth. The Rural Educator, 33, 7-19.

Irvin, M. J., Meece, J. L., Byun, S. Y., Farmer, T. W., \& Hutchins, B. C. (2011). Relationship of school context to rural youth's educational achievement and aspirations. Journal of Youth and Adolescence, 40(9), 1225-1242. http://dx.doi.org/10.1007/s10964-011-9628-8

Jensen, L. A. (2003). Coming of age in a multicultural world: Globalization and adolescent cultural identity formation. Applied Developmental Science, 7, 189-196. http://dx.doi.org/10.1207/S1532480XADS0703_10

Lapan, R. T., Tucker, B., Kim, S.-K., \& Kosciulek, J. F. (2003). Preparing rural adolescents for post-high school $\begin{array}{lllll}\text { transitions. Journal of Counseling \& Development, } & \text { 81, 329-342. }\end{array}$ http://dx.doi.org/10.1002/j.1556-6678.2003.tb00260.x

Larson, R. W. (2002). Globalization, societal change, and new technologies: What they mean for the future of adolescence. Journal of Research on Adolescence, 12, 1-30. http://dx.doi.org/10.1111/1532-7795.00023

Lauver, P. J., \& Jones, R. M. (1991). Factors associated with perceived career options in American Indian, White, and Hispanic rural high school students. Journal of Counseling Psychology, 38, 159-166. http://dx.doi.org/10.1037/0022-0167.38.2.159

McGranahan, D. A. (1994). Rural America in the global economy: Socioeconomic trends. Journal of Research in Rural Education, 10(3), 139-148. 
McWhirter E. H., Hackett F., \& Bandalos D. L. (1998). A causal model of the educational plans and career expectations of Mexican American high school girls. Journal of Counseling Psychology, 45, 166-181. http://dx.doi.org/10.1037/0022-0167.45.2.166

Meece, J. L., Hutchins, B. C., Byun, S. Y., Farmer, T. W., Irvin, M. J., \& Weiss, M. (2013). Preparing for adulthood: A recent examination of the alignment of rural youth's future educational and vocational aspirations. Journal of Educational and Developmental Psychology, 3(2), 175-192. http://dx.doi.org/10.5539/jedp.v3n2p175

Mello, Z. R. (2008). Gender variation in developmental trajectories of educational and occupational expectations and attainment from adolescence to adulthood. Developmental Psychology, 44(4), 1069-1080. http://dx.doi.org/10.1037/0012-1649.44.4.1069

Petrin, R. A, Schafft, K. A, \& Meece, J. L. (2014). Educational sorting and residential aspirations among rural high school students: What are the contributions of schools and educators to rural brain drain? American Educational Research Journal, 51(2), 294-326. http://dx.doi.org/10.3102/0002831214527493.

Provasnik, S., KewalRamani, A., Coleman, M. M., Gilbertson, L., Herring, W., \& Xie, Q. (2007). Status of education in rural America (NCES 2007-040). Washington, DC: National Center for Education Statistics, Institute of Education Sciences, U.S. Department of Education. http://dx.doi.org/10.1007/s10964-011-9690-2

Raudenbush, W. S., \& Bryk, A.S. (2002). Hierarchical linear models: Applications and data analysis methods (2nd ed.). Thousand Oaks: Sage Publications.

Rojewski, J. W. (1999). Career-related predictors of work-bound and college-bound status of adolescents in rural and nonrural areas. Journal of Research in Rural Education, 15, 141-156. Retrieved from http://www.jrre.psu.edu/articles/v15,n3,p141-156,Rojewski.pdf

Schneider, B., \& Stevenson, D. (1999). The Ambitious Generation: America's Teenagers, Motivated but Directionless. New Haven, CT and London, England: Yale University Press.

Schoon, I. (2006). Risk and resilience. Adaptations in changing times. Cambridge: Cambridge University Press. http://dx.doi.org/10.1017/CBO9780511490132

Schoon, I., Martin, P., \& Ross, A. (2007). Career transitions in times of social change. His and her story. Journal of Vocational Behavior, 70, 78-96. http://dx.doi.org/10.1016/j.jvb.2006.04.009

Shapka, J. D., Domene, J. F., \& Keating, D. P. (2006). Trajectories of career aspirations through adolescence and young adulthood: Early math achievement as a critical filter. Educational Research and Evaluation, 12, 347-358. http://dx.doi.org/10.1080/13803610600765752

Stracuzzi, N. F. (2009). Youth aspirations and sense of place in a changing rural economy: The Coos Youth Study. Durham, NH: Carsey Institute.

U.S. Bureau of Labor Statistics. (2009). Household data annual averages, Table 11. Employed persons by detailed occupation, sex, race, and Hispanic or Latino ethnicity. Washington, DC: U.S. Bureau of Labor Statistics. Retrieved from http://www.bls.gov/cps/cpsaat11.pdf

U.S. Bureau of Labor Statistics. (2000). Standard Occupational Classification (SOC) User Guide. Retrieved from http://www.bls.gov/soc/2000/socguide.htm

U.S. Department of Agriculture. (2013). Rural America at a Glance, 2013 Edition. Washington, DC. Retrieved from http://www.ers.usda.gov

U.S. Department of Agriculture. (2005). The $20^{\text {th }}$ Century Transformation of U.S. Agriculture and Farm Policy. Washington, DC. Retrieved from http://www.ers.usda.gov/publications/eib-economic -information-bulletin/eib3.aspx\#.Ut14Xf30CqA 


\section{Appendix}

\begin{tabular}{|c|c|}
\hline Dependent variables & \\
\hline Educational aspirations & $\begin{array}{l}\text { Variable based on the question of "How far in school would you most like to go?". The original given options } \\
\text { were } 1=\text { Less than high school graduation, } 2=\text { High school graduation or GED only, } 3=\text { Attend or complete a } \\
\text { 2-year school course in a community college, occupational, or trade school, } 4=\text { Attend college, but not } \\
\text { complete a } 4 \text {-year degree, } 5=\text { Graduate from college, } 6=\text { Obtain a Master's degree or equivalent, } 7=\text { Obtain a } \\
\text { Ph.D., M.D., or other advanced degree, and } 8=\text { don't know. This variable was transformed into years of } \\
\text { schooling (e.g., } 2=12,7=22 \text { ), with the exclusion of the "don't know" category. }\end{array}$ \\
\hline Occupational aspirations & $\begin{array}{l}\text { Variable based on the question of "What kind of job or occupation will you most like to have at age } 30 \text { ?" The } \\
\text { research team standardized responses using the Standard Occupational Classification (SOC) numeric coding } \\
\text { structure (U.S. Bureau of Labor Statistics, 2000). The nontraditionality of career choice was based on the } \\
\text { percentage of the opposite gender employed in a desired occupation (U.S. Bureau of Labor Statistics, 2009) } \\
\text { and was treated as a continuous variable with higher scores representing greater nontraditionality. }\end{array}$ \\
\hline \multicolumn{2}{|l|}{ Independent variables } \\
\hline \multicolumn{2}{|l|}{ Family characteristics } \\
\hline Economic hardship & $\begin{array}{l}\text { Variable measured the constraints felt by the adolescent relating to difficulty over paying bills and struggles } \\
\text { with having enough money to buy items for the family. This measure was measured by averaging three items } \\
\text { with five-point scales of never-all of the time to the following statements: "there is not enough money in my } \\
\text { family to pay bills (Item 1)."; "We don't have enough money in my family for things that are important (Item } \\
\text { 2)."; and "We don't have enough money to buy things my family needs or wants (Item 3)." Reliability statistics } \\
\text { were .879; Item factor loadings ranged from } .889 \text { (Items } 1 \text { and 3) to } .920 \text { (Item 2). }\end{array}$ \\
\hline Parental education & $\begin{array}{l}\text { Student reported the highest level of their parents' education. The original given options were } 1=\text { Did not finish } \\
\text { high school, } 2=\text { Graduated from high school or completed a GED, } 3=\text { Had some college education but did not } \\
\text { complete a degree, } 4=\text { Graduated from a two-year school, } 5=\text { Graduated from a four-year college or university, } \\
6=\text { Completed a Master's degree, } 7=\text { Completed a Ph.D., M.D., or other advanced professional degree, } 8=\text { don't } \\
\text { know. Higher one between mother's and father's educational attainment was chosen and transformed into } \\
\text { years of schooling (e.g., } 1=11,7=22 \text { ). }\end{array}$ \\
\hline Two-parent family & $\begin{array}{l}\text { Student indicated with whom he/she currently live (e.g., mother, father, stepmother, stepfather, and so on). } \\
1=\text { both mother and father, } 0=\text { otherwise. }\end{array}$ \\
\hline Family size & Number of siblings. \\
\hline $\begin{array}{l}\text { Parent respect and } \\
\text { identification }\end{array}$ & $\begin{array}{l}\text { Variable assessed the extent to which students identified with and respected their parents. was measured by } \\
\text { averaging three items with six-point scales of disagreement-agreement to the following statements: "When I } \\
\text { grow up, I'd like to be like my parent/guardian (Item 1)."; "I have a lot of respect for my parent/guardian (Item } \\
\text { 2)."; and "I really enjoy spending time with my parent/guardian (Item 3)." Reliability statistics (i.e., } \\
\text { Cronbach's alpha) were .764. Item factor loadings ranged from .717 (Item 1) to .898 (Item 3). }\end{array}$ \\
\hline $\begin{array}{l}\text { Parental expectations for } \\
\text { child's college education }\end{array}$ & $\begin{array}{l}\text { Variable based on the questions "How disappointed you think you mother or female guardian would be if you } \\
\text { didn't graduate from college?" and "How disappointed you think you mother or female guardian would be if } \\
\text { you didn't graduate from college?" Range of original responses for each question were from } 1=\text { not at all } \\
\text { disappointed to } 6=\text { very disappointed. These original responses for each question were summed up and } \\
\text { included as a continuous variable. }\end{array}$ \\
\hline \multicolumn{2}{|l|}{ Student characteristics } \\
\hline Race/ethnicity (\%) & Students indicated their racial or ethnic background. \\
\hline \multicolumn{2}{|l|}{ White } \\
\hline \multicolumn{2}{|l|}{ Black } \\
\hline Hispanic & \\
\hline
\end{tabular}




\begin{tabular}{|c|c|}
\hline \multicolumn{2}{|l|}{ Native Americans } \\
\hline Grade level & Students indicated their grade. $1=9$ th, $2=10$ th, $3=11$ th, and $4=12$ th. \\
\hline Rural identity & $\begin{array}{l}\text { Variable assessed the extent of rural identity development in adolescents. was measured by averaging five } \\
\text { items with responses on six-point scales of not at all like me-a lot like me to the statements: "I have a clear } \\
\text { sense of my rural background and what it means for me (Item 1)."; "I am happy that I live in a rural community } \\
\text { (Item 2)."; "I have a strong sense of belonging to my own rural community (Item 3)."; "I have a lot of pride in } \\
\text { my rural background (Item 4)."; "I feel a strong attachment towards my rural background (Item 5)." Reliability } \\
\text { statistics were .914. Item factor loadings ranged from .745 (Item 1) to .913 (Item 4). }\end{array}$ \\
\hline $\begin{array}{l}\text { Positive perception of } \\
\text { economic opportunity in } \\
\text { home community }\end{array}$ & $\begin{array}{l}\text { Variable assessed the extent to which students positively perceived economic opportunity in their home } \\
\text { community. was measured by averaging three items with responses on six-point scales of } \\
\text { disagreement-agreement: "It is easy to get a good paying job around here (Item 1)"; "A lot of people get } \\
\text { benefits like health or vacation time for most jobs in this area (Item 2)."; and "There are good jobs in the area } \\
\text { for people like me (Item 3)" Reliability statistics were .672. Item factor loadings ranged from .803 (Item 3) } \\
\text { to .782 (Item 1). }\end{array}$ \\
\hline Residential Aspirations & $\begin{array}{l}\text { Students indicated where they wanted to live when they were } 30 \text { years old. Response options included, "home } \\
\text { state, another state, or have not thought or decided." }\end{array}$ \\
\hline \multicolumn{2}{|l|}{ School Characteristics } \\
\hline $\begin{array}{l}\text { Proportion of students } \\
\text { receiving free lunch }\end{array}$ & Percent students on free lunch. Information from 2004-05 NCES Common Core of Data. \\
\hline Pupil-teacher ratio & Pupil-teacher ratio. Information from 2004-05 NCES Common Core of Data. \\
\hline School location: rural & $\begin{array}{l}\text { The original locale codes were } 31=\text { rural, fringe, } 32=\text { rural, distant, } 33=\text { rural remote, } 41=\text { town, fringe, } 42=\text { town, } \\
\text { distant, and } 43=\text { town, remote. The categories were collapsed into a dichotomous variable (rural=1 vs. town=0). }\end{array}$ \\
\hline \multicolumn{2}{|l|}{ Schooling experiences } \\
\hline College prep program & Student indicated a high school program in which they were enrolled. $1=$ college prep track, $0=$ else \\
\hline Retention & Students indicated whether they had ever been held or kept back a grade. $1=$ yes, $0=$ no. \\
\hline Achievement & $\begin{array}{l}\text { Students indicated their grades. 1=Mostly A's to 8=Below D's. The original scales were reversed (1=below } \\
\text { D's; 8=Mostly A's). }\end{array}$ \\
\hline Postsecondary preparation & $\begin{array}{l}\text { Variable assessed the extent to which adolescents prepare for their future after high school graduation. This } \\
\text { variable was measured by averaging four items with four-point scales of never-more than } 5 \text { times to the } \\
\text { statements: "Talked with a guidance counselor or other advisor about college? (Item 1)"; "Visited a college } \\
\text { campus? (Item 2); "Searched for college courses or programs available by the internet? (Item 3)"; "Talked } \\
\text { with your parents about how to pay for college? (Item 4)"; Reliability statistics for one-factor model are .656; } \\
\text { Item loadings for one-factor model range from .615 (Item 2) to .741 (Item 3). }\end{array}$ \\
\hline Academic self-concept & $\begin{array}{l}\text { Variable assessed adolescents' perceptions of their academic competence in multiple school subjects. This } \\
\text { variable was measured by averaging five items with seven-point scales of not at all good-very good to the } \\
\text { statements: "English / language arts? (Item 1)"; "Mathematics? (Item 2)"; "Science? (Item 3)"; "Social } \\
\text { studies? (Item 4)"; and "Other classes? (Item 5)." Its reliability statistics were .731; Item factor loadings } \\
\text { ranged from .515 (Items 2) to .788 (Item 4). }\end{array}$ \\
\hline School valuing & $\begin{array}{l}\text { Variable assessed how much adolescents had feelings of positive value for school and whether they view it as } \\
\text { a pathway for later opportunities in life. This variable was measured by averaging seven items with six-point } \\
\text { scales of disagreement-agreement to the statements: "School is one of the most important things in my life } \\
\text { (Item 1)."; "Most of what I learn in school will be useful when I get a job (Item 2)."; "Dropping out of school } \\
\text { would be a huge mistake for me (Item 3)."; "School is more important than most people think (Item 4)."; } \\
\text { "School is important to getting a good job (Item 5)."; "The kind of education I'm getting here will help me later } \\
\text { on (Item 6)."; "What I study in school seems important to me (Item 7)."; Reliability statistics were .851. Item } \\
\text { loadings ranged from .529 (Item 3) to .815 (Item 7). }\end{array}$ \\
\hline School belonging & $\begin{array}{l}\text { Variable assessed the extent of personal belonging, respect, and support that students feel in school. This } \\
\text { variable was measured by averaging } 11 \text { items with five-point scales of completely false-completely true to the } \\
\text { statements: "I feel a real part of my school (Item 1)."; "People notice when I'm good at something (Item 2)."; }\end{array}$ \\
\hline
\end{tabular}




\begin{tabular}{|c|c|}
\hline & $\begin{array}{l}\text { "Other students in this school take my opinions seriously (Item 3)."; "Most teachers at my school are interested } \\
\text { in me (Item 4)."; "There's at least one teacher or adult in this school that I can talk to if I have a problem (Item } \\
\text { 5)."; "People at this school are friendly to me (Item 6)."; "I am included in lots of activities at my school (Item } \\
\text { 7)."; "I am treated with as much respect as other students (Item 8)."; "The teachers here respect me (Item 9)."; } \\
\text { "People know I can do good word (Item 10)."; and "Other students like the way I am (Item 11)." Reliability } \\
\text { statistics were .905. Item factor loadings ranged from .538 (Item 5) to .791 (Item 8). }\end{array}$ \\
\hline $\begin{array}{l}\text { Breadth of activity } \\
\text { involvement }\end{array}$ & $\begin{array}{l}\text { Students reported whether they participated in each of } 20 \text { activities (e.g., team sports, student government, } \\
\text { performing arts, etc.) and the number of times per week during the current school year on a 6-point scale ( } 1= \\
\text { not available; } 2=\text { four or more days a week; } 3=\text { two-three days a week; } 4=\text { once a week; } 5=\text { once or twice; } 6 \\
\text { = not at all). The } 20 \text { items were collapsed into } 5 \text { activity types using Eccles and Barber's (1999) five activities } \\
\text { clusters: team sports ( } 1 \text { item), school involvement (e.g., cheerleading, student government, yearbook } \\
\text { committee; } 3 \text { items, alpha }=.77 \text { ), academic clubs (e.g., honor society; } 4 \text { items, alpha }=.81 \text { ), performing arts } \\
\text { (school or community band; } 1 \text { item), and prosocial activities(e.g., community service organizations, religious } \\
\text { groups; } 6 \text { items, alpha }=.90 \text { ). Additionally, we created a career clubs category (e.g., Future Business Leaders } \\
\text { of America, Future Farmers of America; } 5 \text { items, alpha }=.89 \text { ). The purpose of aggregating the activities in this } \\
\text { manner was to examine trends by domain. Breadth was calculated as the total number of activity types reported } \\
\text { by involved youth, ranging from } 0 \text { (no reported involvement) to } 6 \text { (involvement reported in all } 6 \text { activity } \\
\text { contexts). }\end{array}$ \\
\hline $\begin{array}{l}\text { Teacher's educational } \\
\text { expectations for student }\end{array}$ & $\begin{array}{l}\text { Teachers indicated how far in school they thought each student would go. Original responses (see parental } \\
\text { education) were transformed into years of schooling (e.g., } 1=11,7=22 \text { ). }\end{array}$ \\
\hline $\begin{array}{l}\text { Teacher's assessment of } \\
\text { social development of } \\
\text { student }\end{array}$ & $\begin{array}{l}\text { Teachers assessed social and behavioral characteristics of the student using the Interpersonal Competence } \\
\text { Scale (ICS-T) developed by Cairns, Leung, Gest, and Cairns (1995). This measure consisted of } 18 \text { items } \\
\text { related to five dimensions of social development of the student, including (1) aggressiveness (argues, trouble at } \\
\text { school, fights), (2) popularity (popular with boys, popular with girls, lots of friends), (3) academic/school } \\
\text { performance (spelling, math), (4) social affiliation (smile, friendly), (5) 'Olympian' quantities (sporting } \\
\text { prowess, attractiveness and tendency to win at games, sports, etc.) Each dimension was scored on a 7-point } \\
\text { scale and the average score across the five dimensions was calculated, ranging from } 1 \text { (low-level social } \\
\text { development) to } 7 \text { (high-level social development). See Cairns et al. (1995) for more information about this } \\
\text { measure. }\end{array}$ \\
\hline
\end{tabular}

\section{Copyrights}

Copyright for this article is retained by the author(s), with first publication rights granted to the journal.

This is an open-access article distributed under the terms and conditions of the Creative Commons Attribution license (http://creativecommons.org/licenses/by/3.0/). 